\title{
Jurassic magmatism in Dronning Maud Land: synthesis of results of the MAMOG project
}

\author{
P.T. Leat, ${ }^{1}$ M.L Curtis, ${ }^{1}$ T.R. Riley, ${ }^{1}$ and F. Ferraccioli ${ }^{1}$ \\ ${ }^{1}$ British Antarctic Survey, High Cross, Madingley Road, Cambridge CB3 0ET, UK (p.leat@bas.ac.uk)
}

\begin{abstract}
The Jurassic Karoo large igneous province (LIP) of Antarctica, and its conjugate margin in southern Africa, is critical for investigating important questions about the relationship of basaltic LIPs to mantle plumes. Detailed aerogeophysical, structural, anisotropy of magnetic susceptibility (AMS), geochronological and geochemical investigations completed under the British Antarctic Survey's MAMOG project have provided some of the answers. Across most of the area, magma volumes were small compared to those in southern Africa. Jurassic dikes intruding the Archean craton are sparse and the Jutulstraumen trough, a Jurassic rift, is interpreted, from aerogeophysical data, as largely amagmatic. The largest volumes of magma were emplaced along the margin of the craton and close to the Africa-Antarctica rift. Although dikes were emplaced by both vertical and horizontal flow, overwhelmingly magmas in Dronning Maud Land were locally derived, and not emplaced laterally from distant sources. Basaltic magmatism was protracted in Dronning Maud Land (several dike emplacement episodes between 206 and $175 \mathrm{Ma}$ ), and the small magma volumes resulted in highly diverse magma compositions, including picrites and ferropicrites interpreted to have been derived from hot mantle in a mantle plume. The protracted magmatism before the locally $\sim 177 \mathrm{Ma}$ flood lava eruptions, and evidence for a radiating dike swarm, favor a model of mantle plume incubation for 20-30 million years before flood lava eruption.
\end{abstract}

Citation: Leat, P.T., M.L. Curtis, T.R. Riley and F. Ferraccioli (2007). Jurassic magmatism in Dronning Maud Land; results of the MAMOG project, in Antarctica : A Keystone in a Changing World - Online Proceedings of the $10^{\text {th }}$ ISAES, edited by A.K. Cooper and C.R. Raymond et al. USGS Open-File Report 2007-1047, Short Research Paper 033, 4 p.; doi:10.3133/of2007-1047.srp033

\section{Introduction}

Jurassic igneous outcrops are scattered over an area of some $145,000 \mathrm{~km}^{2}$ in Dronning Maud Land, Antarctica (Fig. 1), and include basaltic lava sequences intruded by mafic dikes and other mafic minor intrusions in Vestfjella, Heimefrontfjella (Bjørnnutane, Sembberget) and Kirwanveggen, and dikes and sills in Ahlmannryggen, H.U. Sverdrupfjella, Fossilryggen and Mannefallknausane. There are also Jurassic minor syenite and alkaline granite intrusions along the margins of the Jutulstraumen glacier at Straumsvola, Tvora and Sistefjella (Harris and Grantham, 1993; Harris et al. 2002). These outcrops and subcrops form the remnants of an extension of the Karoo large igneous province (LIP) into Antarctica. The distributions, compositions, age relationships and structures of the igneous rocks of the Dronning Maud Land part of the LIP provide important information on the origin and evolution of the province as a whole that is not available in the more accessible outcrops on the conjugate margin in southern Africa. This paper provides an overview of the British Antarctic Survey's project 'Magmatism as a Monitor of Gondwana Break-up' (MAMOG) which ran from 2000 to 2005. This project aimed to collect and use data from the Dronning Maud Land area to test models for mantle processes responsible for the generation of the huge volumes of magma produced during the rifting of Antarctica from southern Africa during the Jurassic first stages of Gondwana break-up. The data discussed were mostly produced by the project, along with significant related work by other researchers.

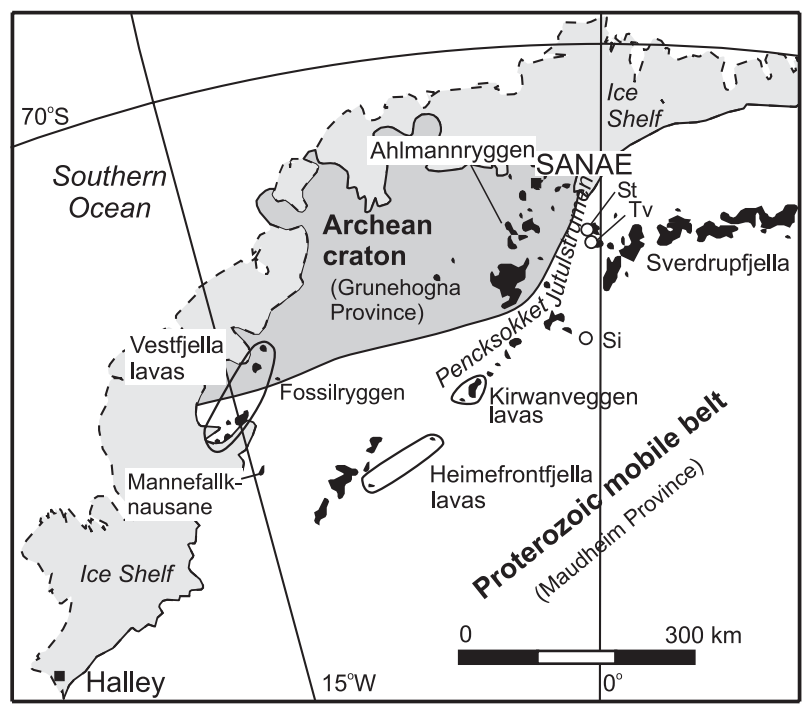

Figure 1. Location map of the Karoo LIP in western Dronning Maud Land and its relationship to basement provinces. Alkaline intrusions: St, Straumsvola; Tv, Tvora; Si, Sistefjella.

\section{Aims of the project}

The project aimed to provide critical information to inform debates on the role of mantle plumes in the formation of basaltic large igneous provinces (LIP) generally, and the Karoo LIP in particular. Much evidence has accumulated to suggest that basaltic LIPs globally are linked to upwelling mantle plumes sourced from the base or interior of the mantle (e.g. McKenzie and White, 1989; Campbell \& Griffiths, 1990). Nevertheless, this view has recently been challenged, notably by Anderson (2000) 
and Foulger (2002). Following the insights of McKenzie and White (1989), Campbell and Griffiths (1990) and Duncan and Richards (1991), many authors have interpreted the Karoo igneous province as the result of mantle plume-lithosphere interactions (e.g. Cox, 1992; Storey, 1995; Storey et al., 2001). Nevertheless, there have been several uncertainties: Did the mantle plume play an 'active' role (Storey and Kyle, 1997) in rifting Gondwana apart, or a purely 'passive' role (White and McKenzie, 1989) in generating magmatism beneath an already rifting continent? Did the arrival of the head of the mantle plume at the base of the lithosphere cause a massive outburst of volcanism (impact model; Campbell and Griffiths, 1990), or did the mantle plume arrive much earlier than the voluminous flood basalts, possible contributing to weakening of the lithosphere (incubation model: Kent et al., 1992)? Can the thermal insulation of the upper mantle by the supercontinent lithosphere account for high mantle temperatures and flood basalt eruption in the absence of a specific Karoo mantle plume (Hawkesworth et al., 1999)? The MAMOG project was designed to test these issues, using multidisciplinary structural, geochronological, geochemical and aerogeophysical data and centered on the Dronning Maud Land part of the province.

\section{Regional setting}

The basement geology of Dronning Maud Land consists of two provinces (Fig. 1). The Grunehogna province consists of Archean cratonic rocks overlain by weakly metamorphosed c. 900-1100 Ma volcanosedimentary rocks of the Ritscherfjella Supergroup (Wolmarans and Kent, 1982). To the east and south of the craton lies the Maudheim province, which consists of Mesoproterozoic amphibolitic to granulitic rocks of the Svedrupfjella Group (Groenewald et al., 1991). The structural relationship between the two provinces has been uncertain (Proterozoic thrust, Pan-African shear zone, Mesozoic rift or a combination of two or more: Corner (1994)).

\section{Aerogeophysics}

We flew a high-resolution aerogeophysical survey of the area of Dronning Maud Land straddling the confluence of the Jultulstraumen and Pencksokket glaciers during the 2001-02 Antarctic field season (Ferraccioli et al., 2005a,b). This location was chosen in order to determine the structure and origin of the trough, to observe the contact between the Archean and Proterozoic terranes, and to find the amount of magmatism in the structures. 15,500 line $\mathrm{km}$ of aeromagnetic data were collected with a $1 \mathrm{~km}$ line spacing. Interpretation of the data indicate that the trough is a Jurassic rift that followed the Grunehogna-Maudheim province boundary. Aeromagnetic and gravity anomalies closely correlate with the Straumsvola, Tvora and Sistefjella intrusions, indicating that they are underlain by mafic intrusions. However, there appear to be no further similar intrusions hidden beneath the ice. The aeromagnetic data gave no indication of significant dikes or lava sequences in the rift, contrasting with prominent dike swarms like the Okavango dike swarm in Botswana (Le Gall et al., 2002). The rift is therefore interpreted as largely amagmatic (or less likely filled by a thick sequence of sediments).

\section{Geochronology}

The Mesozoic lavas and intrusions of Dronning Maud Land have proved difficult to date. ${ }^{40} \mathrm{Ar} /{ }^{39} \mathrm{Ar}$ data are affected by alteration, recoil and excess ${ }^{40} \mathrm{Ar}$ (Zhang et al., 2003; Riley et al., 2005; Fazel, 2007), and zircon-bearing silicic magmas are essentially non-existent. Nevertheless, ideas on the geochronological framework of the Karoo LIP, including its Antarctic parts, have evolved considerably over the last decade. Duncan et al. (1997) used Ar-Ar analyses to propose that the volumetric peak of Karoo volcanism was at ca. $183 \pm 1 \mathrm{Ma}$, as represented by the lavas around Lesotho, the Lebombo Monocline and, in Dronning Maud Land, at Kirwanveggen. The recalibrated data set of Riley and Knight (2001) confirmed the $\sim 183$ Ma peak in Karoo magmatism and the rapid eruption of the $10 \mathrm{~km}$ Lebombo monocline lavas was confirmed by U-Pb dating of zircons from the upper rhyolitic members (Riley et al., 2004). Subsequent work has tended to show a more complex picture, with more magmatic episodes extending from 184.7 to $178.3 \mathrm{Ma}$ in southern Africa (e.g. Le Gall et al., 2002; Jourdan et al., 2005) and 206.1 to 174.8 Ma in Dronning Maud Land, with distinct dyke emplacement episodes at 206-203 Ma, ca $190 \mathrm{Ma}$ and 178-175 Ma (Riley et al., 2005; Curtis et al., in review); these age distributions are consistent with the unpublished Antarctic data set of Fazel (2007). The last of these episodes corresponds to the $177 \mathrm{Ma}$ lavas and gabbro intrusions at Vestfjella (Zhang et al., 2003). Jourdan et al. (2005) suggested that magmatism migrated regionally from south to north over the total period of activity, but this was challenged by Riley et al. (2006b), who pointed out, inter alia, that the interpretation is not consistent with age distributions in Dronning Maud Land.

\section{Geochemistry}

Luttinen and Furnes (2000) showed that the Vestfjella basaltic lavas can be divided into several geochemical groups that are related to chemical heterogeneity of mantle sources and differing magmatic processes. The chemical variation is similar to that seen in lavas of southern Africa (Sweeney et al., 1995; Marsh et al., 1997). However, in the Ahlmannryggen area of Dronning Maud Land, a very wide range of compositions is seen in Jurassic dykes that covers almost the entire chemical range of the rest of the province, as well as some apparently unique to the area (Riley et al., 2005). The Ahlmannryggen area is underlain by Archean craton, that experienced little contemporaneous extension, and whose lithosphere was little thinned by the rifting (Riley et al., 2005; Ferraccioli et al., 2005b). The wide range in magma 
compositions in the Ahlmannryggen area (Riley et al., 2005 ) is likely a result of the protracted and low-volume character of the magmatism - the individual magma batches had little opportunity to mix with a large volume of magma or to thermally assimilate lithosphere. Importantly, picrite and ferropicrite dikes emplaced at $\sim 190$ Ma must have been derived from relatively hot mantle, implying the presence of a mantle plume. Geochemical correlations can be used to indicate that this plume is now represented by the Shona-Discovery-Bouvet group of hot spots in the South Atlantic (Andres et al., 2002; le Roux et al., 2002; Riley et al., 2003).

\section{Relationship of Magmatism to Structure}

Clear basement control on the distribution of Jurassic igneous rocks has become apparent. The largest volumes of magma were emplaced in the area occupied by the Maudheim Province, or along the southwestern margins of the craton, where lava sequences (Vestfjella, Heimefrontfjella and Kirwanveggen) and voluminous gabbroic sheet-like intrusions related to them (Utpostane and Muren, both in Vestfjella) are preserved (Luttinen and Furnes, 2000; Vuori and Luttinen, 2003; Luttinen and Vuori, 2006). Only limited volumes of magma appear to have traversed the Archean craton, and Jurassic magmatism in the Ahlmannryggen area consists entirely of a low-density group of dikes (Riley et al., 2005), which we interpret as unlikely ever to have been overlain by a significant lava sequence. Our aerogeophysical work has shown that the Jutulstraumen trough does not contain a voluminous dike swarm or abundant intrusions therefore probably was a largely amagmatic rift.

\section{Long-distance magma flow}

Recent interpretations of the Ferrar magmas, a subprovince of the Karoo LIP, contemporaneous with the later Karoo lavas (Riley and Knight, 2001), have strongly suggested that the basaltic magmas flowed laterally through the crust from a single source area over distances of $>4100 \mathrm{~km}$ (Elliot et al., 1999; Leat, in press). The source area is thought to be the rift between Antarctica and southern Africa and the Weddell Sea (Elliot and Fleming, 2000). This raises the possibility of longdistance lateral flow of some of the magmas emplaced in Dronning Maud Land, an important consideration, as magmas emplaced laterally cannot be used to interpret melting conditions in underlying mantle. Nevertheless, geochemical correlations do not suggest significant lateral emplacement of magma in Dronning Maud Land. A sill from Mannefallknausane is similar to a Karoo-like sill in the Theron Mountains (south of Halley), and both are interpreted to have flowed through the crust from the Africa-Antarctica rift zone (Leat et al., 2006).

\section{Structural and AMS studies on dikes}

Magma flow directions in sills and dykes can be determined structurally and by measuring anisotropy of magnetic susceptibility (AMS). These methods have been successfully applied to Karoo dikes in Antarctica and southern Africa. Curtis et al. (under review) showed that both vertical and sub-horizontal magma flow directions occur in dikes along the Jutulstraumen rift, and Riley et al., (2006a) found a similar combination of flow directions in an approximately conjugate dike swarm in South Africa.

\section{Rifts and dike swarms}

Three dike swarms in Dronning Maud Land (Vestfjella, Ahlmannryggen, H.U. Sverdrupfjella) emplaced at $\sim 176-178$ Ma converge on a point along the continental margin of Dronning Maud Land (Curtis et al., under review). This point is close to the Nuanetsi triple junction where the Lebombo and Sabi monoclines and $\sim 178$-179 Ma Okavango dike swarm (Le Gall et al., 2002) converge in southern Africa. The convergence of the Dronning Maud Land and African dike swarm at the some location in rifting Gondwana is very strong evidence that these features form a true radiating dike swarm, providing strong evidence for an underlying mantle plume.

\section{Conclusions}

The Dronning Maud Land part of the Karoo LIP provides important information on the origin and evolution of the igneous province as whole. There is a record of protracted emplacement of mafic dikes over 20$30 \mathrm{Ma}$, including picrites and ferropicrites that are apparently unique within the LIP and are interpreted to have been derived from hot mantle. There is evidence for a $\sim 177$ Ma radiating dike swarm. These features support a model of prolonged incubation of a mantle plume beneath the Karoo province before eruption of the voluminous flood lavas. A very wide range of magma compositions is preserved in Dronning Maud Land, especially in dikes intruding the Grunehogna craton. This feature is interpreted to be a result of the protracted, low volume nature of the magmatism.

Acknowledgements. We thank the British Antarctic Survey and the South African National Antarctic Programme for logistic support. We thank to numerous colleagues for their scientific contributions to the project, notably P. C. Jones, I.L. Millar, and A. Fazel. Reviews by Dave Elliot and Phil Kyle are gratefully acknowledged.

\section{References}

Anderson, D.L. (2000), The thermal state of the upper mantle; no role for mantle plumes, Geophys. Res. Lett., 27, 3623-3626.

Andres, M., J. Blichert-Toft and Schilling, J.-G. (2002), Hafnium isotopes in basalts from the southern Mid-Atlantic Ridge from $40^{\circ} \mathrm{S}$ to $55^{\circ} \mathrm{S}$ : Discovery and Shona plume-ridge interactions and the role of recycled sediments. Geochem. Geophys. Geosyst., 3, No. 10, 8502, doi: 10.1029/2002GC000324.

Campbell, I.H. and R.W. Griffiths (1990), Implications of mantle plume structure for the evolution of flood basalts, Earth Planet. Sci. Lett., 99, 79-93.

Corner, B. (1994), Geological evolution of western Dronning Maud Land within a Gondwana framework: geophysics subprogramme, Final Report to SACAR.

Curtis, M.L., T.R. Riley, W.H. Owens, P.T. Leat and R.A. Duncan (in review), The form, distribution and anisotropy of magnetic susceptibility of Lower Jurassic dykes in H.U. Sverdrupfjella, 
Dronning Maud Land, Antarctica. Implications for dyke emplacement. J. Struct. Geol

Cox, K. G. (1992), Karoo igneous activity, and the early stages of the break-up of Gondwanaland, in Magmatism and the Causes of Continental Break-up, edited by B.C. Storey, T. Alabaster and R.J. Pankhurst, Spec. Publ. Geol. Soc, London, 68, 137-148.

Duncan, R.A. and M.A. Richards (1991), Hotspots, mantle plumes, flood basalts, and true polar wander. Rev. Geophys., 29, 31-50.

Duncan, R.A., P.R. Hooper, J. Rehacek, J.S. Marsh, and A.R. Duncan (1997), The timing and duration of the Karoo igneous event, southern Gondwana. J. Geophys. Res. 102, 18127-18138.

Groenwald, P.B., G.H. Grantham and M.K. Watkeys (1991). Geological evidence for a Proterozoic to Mesozoic link between southeastern Africa and Dronning Maud Land, Antarctica. J. Geol. Soc. London, $148,1115-1123$.

Elliot, D.H. and T.H. Fleming (2000), Weddell triple junction: the principle focus of Ferrar and Karoo magmatism during initial breakup of Gondwana, Geology, 28, 539-542.

Elliot, D.H., T.H. Fleming, P.R. Kyle and K.A. Foland (1999), Longdistance transport of magmas in the Jurassic Ferrar large igneous province, Antarctica, Earth Planet. Sci. Lett., 167, 89-104.

Fazel, A. (2007), Dykes as Tracers of Continental Break-up: Argon Geochronology of Western Dronning Maud Land. PhD Thesis, Open University, UK.

Ferraccioli, F., P.C. Jones, M.L. Curtis, P.T. Leat, and T.R. Riley (2005a), Tectonic and magmatic patterns in the Jutulstraumen rift(?) region, East Antarctica, as imaged by high-resolution aeromagnetic data, Earth Planets Space, 57, 767-780.

Ferraccioli, F., P.C. Jones, M.L. Curtis and P.T. Leat (2005b). Subglacial imprints of early Gondwana break-up as identified from high resolution aerogeophysical data over western Dronning Maud Land, East Antarctica, Terra Nova, 17, 573-579.

Foulger, G.R. (2002). Plumes, or plate tectonic processes? Astron. Geophys., 43, 6.19-6.23.

Harris, C. and G.H. Grantham (1993). Geology and petrogenesis of the Straumsvola nepheline syenite complex, Dronning Maud Land, Antarctica. Geol. Mag. 130, 513-532.

Harris, C., W.P. Johnstone and D. Phillips (2002). Petrogenesis of the Mesozoic Sistefjella syenite intrusion, Dronning Maud Land, Antarctica, and surrounding low- $\delta{ }^{18} \mathrm{O}$ lavas, South Afric. J. Geol. 105, 205-226.

Hawkesworth, C., S. Kelley, S. Turner, A. le Roex and B. Storey (1999), Mantle processes during Gondwana break-up and dispersal, J. Afric. Earth Sci., 28, 239-261.

Jourdan, F., G. Féraud, H. Bertrand, A.B. Kampunzu, , G. Tshoso, M.K. Watkeys, and B. Le Gall (2005), Karoo large igneous province: brevity, origin, and relation to mass extinction questioned by new ${ }^{40} \mathrm{Ar} /{ }^{39} \mathrm{Ar}$ age data, Geology, 33, 745-748.

Kent, R.W., M. Storey A.D. Saunders (1992), Large igneous provinces: sites of plume impact or plume incubation? Geology, 20, 891-894.

Leat, P.T. (in press), On the long-distance transport of Ferrar magmas, in Physical Geology of High-level Magmatic Systems, edited by N. Petford and K. Thomson, Spec. Publ. Geol. Soc. London.

Leat, P.T., A.V. Luttinen, B.C. Storey and I.L. Millar (2006), Sills of the Theron Mountains, Antarctica: evidence for long distance transport of mafic magmas during Gondwana break-up, in Dyke Swarms - Time Markers of Crustal Evolution, edited by E. Hanski, S. Mertanen, T. Rämö and J. Vuollo, pp. 183-199, Taylor \& Francis, London.

Le Gall, B., G. Tshoso, F. Jourdan, G. Féraud, H. Bertrand, J.J. Tiercelin, A.B. Kapunzu, M.P. Modisi, J. Dyment and M. Maia (2002), ${ }^{40} \mathrm{Ar} /{ }^{39} \mathrm{Ar}$ geochronology and structural data from the giant Okavango and related mafic dyke swarms, Karoo igneous province, northern Botswana, Earth Planet. Sci. Lett, 202, 595-606.

le Roux, P.J., A.P. le Roex, J.G. Schilling, N. Shimizu, W.W. Perkins and N.J.G. Pearce (2002), Mantle heterogeneity beneath the southern Mid-Atlantic Ridge: trace element evidence for contamination of ambient asthenospheric mantle, Earth Planet. Sci. Lett., 203, 479-498.

Luttinen, A.V. and H. Furnes (2000), Flood basalts of Vestfjella: Jurassic magmatism across an Archaean-Proterozoic lithospheric boundary in Dronning Maud Land, Antarctica, J. Petrol. 41, 12711305.

Luttinen, A.V. and S.K. Vuori (2006). Geochemical correlations between Jurassic gabbros and basaltic rocks in Vestfjella, Dronning Maud Land, Antarctica, in Mafic Dykes - Time Markers of Crustal Evolution, edited by E. Hanski, S. Mertinen, T. Rämö and J. Vuollo, pp. 201-212, Taylor \& Francis, London.

Marsh, J.S., P.R. Hooper, J. Rehacek, R.A. Duncan, \& A.R Duncan, (1997), Stratigraphy and age of Karoo basalts of Lesotho and implications for correlations within the Karoo igneous province, in Large Igneous Provinces: Continental, Oceanic, and Planetary Flood Volcanism, edited by J.J. Mahoney and M.F. Coffin, Geophysical Monographs, 100, 247-272, American Geophysical Union, Washington D.C.

Riley, T.R. and K.B. Knight (2001), Age of pre-break-up Gondwana magmatism. Antarct. Sci., 13, 99-110.

Riley, T.R., M.L. Curtis, P.T. Leat, M.K. Watkeys, R.A. Duncan, I.L. Millar, and W.H. Owens (2006a), Overlap of Karoo and Ferrar magma types in KwaZulu-Natal, South Africa, J. Petrol., 47, 541-566.

Riley, T.R., P.T. Leat and M.L. Curtis (2006b), Karoo large igneous province: brevity, origin, and relation to mass extinction questioned by new ${ }^{40} \mathrm{Ar} /{ }^{39} \mathrm{Ar}$ age data: comment, Geology, Forum, e109-110, doi: $10.1130 / \mathrm{G} 22380 \mathrm{C} .1$.

Riley, T.R., P.T. Leat, M.L. Curtis, I.L. Millar, R.A. Duncan, and A. Fazel (2005), Early-Middle Jurassic dolerite dykes from western Dronning Maud Land (Antarctica): identifying mantle sources in the Karoo large igneous province, J. Petrol. 46, 1489-1524.

Riley, T.R., P.T. Leat, B.C. Storey, I.J. Parkinson and I.L. Millar (2003), Ultramafic lamprophyres of the Ferrar large igneous province: evidence for a HIMU component, Lithos, 66, 63-76.

Riley, T.R., I.L. Millar, M.K. Watkeys, M.L. Curtis, P.T. Leat, M.B. Klausen and C.M. Fanning (2004), U-Pb zircon (SHRIMP) ages for the Lebombo rhyolites, South Africa: refining the duration of Karoo magmatism, J. Geol. Soc. London, 161, 547-550.

Storey, B.C. (1995), The role of mantle plumes in continental break-up: case histories from Gondwanaland, Nature, 377, 301-308.

Storey, B.C. and P.R. Kyle (1997), An active mantle mechanism for Gondwana break-up, S. Afric. J. Geol. 100, 283-290.

Storey, B.C., P.T. Leat and J.K. Ferris (2001), The location of mantleplume centres during the initial stages of Gondwana break-up, in: Mantle Plumes: their Identification Through Time, edited by R.E. Ernst and K.L. Buchan, Geol. Soc. Am. Spec. Pap. 352, 71-80.

Sweeney, R.J., A.R. Duncan and A.J. Erlank (1994), Geochemistry and petrogenesis of central Lebombo basalts of the Karoo igneous province, J. Petrol. 35, 95-125.

Vuori, S. K. and A.V. Luttinen (2003), The Jurassic gabbroic intrusions of Utpostane and Muren: insights into Karoo-related plutonism in Dronning Maud Land, Antarctica, Antarct. Sci., 15, 283-301.

White, R. and D. McKenzie (1989), Magmatism at rift zones: the generation of volcanic continental margins and flood basalts, J. Geophys. Res., 94, 7685-7729.

Wolmarans, L.G. and L.E. Kent (1982), Geological investigations in western Dronning Maud Land, Antarctica - a synthesis, S. Afric. J. Antarct. Res., 2.

Zhang, X., A.V. Luttinen, D.H. Elliot, K. Larsson and K.A. Foland (2003), Early stages of Gondwana break-up: the ${ }^{40} \mathrm{Ar} /{ }^{39} \mathrm{Ar}$ geochronology of Jurassic basaltic rocks from western Dronning Maud Land, Antarctica, and implications for the timing of magmatic and tectonic events, J. Geophys. Res. 108, B9, 2449, doi: 10.1029/2001JB001070. 